\title{
-Derleme
}

\section{COVID-19 pandemisinin maternal-neonatal etkileri ve yönetimi}

\section{Maternal-neonatal effects and management of COVID-19 pandemic}

\author{
*Gamze Acavut ${ }^{1} \square$ Ramazan Erda Pay ${ }^{2} \square$, Mustafa Ulubay ${ }^{3} \square$, Özlem Evliyaoğlu Bozkurt³ $\square$
}

${ }^{1}$ Ankara Medipol Üniversitesi, Sağlık Bilimleri Fakültesi-Ebelik Bölümü, Ankara, Türkiye

${ }^{2}$ Bingöl Kadın Doğum ve Çocuk Hastalıkları Hastanesi-Kadın Doğum Servisi, Bingöl, Türkiye

${ }^{3}$ Sağlık Bilimleri Üniversitesi, Gülhane Eğitim ve Araştırma Hastanesi, Kadın Hastalıkları ve Doğum, Ankara, Türkiye

\section{Öz}

Coronavirüs hastalığı, SARS-Cov-2 virüsünün neden olduğu solunum yolu hastalığıdır. İnsanlar arasında hızlı bir yayılım gösteren bu virüs pandemi olarak ilan edilmiştir ve tüm dünya sağlığını tehdit etmektedir. Damlacık yolu ve kontamine yüzeyler ile temas sonrası bulaşabilen virüs riskli gruplarda ölümcül olabilmektedir. Bu nedenle gebeler ve yenidoğanlar üzerinde hassasiyetle durulması gereken gruplardandır. Gebelikte ortaya çıkan anatomik ve fizyolojik değişiklikler, yenidoğanın immatür olması COVID-19 pandemisinin ele alınmasını önemli hale getirmiştir. COVID-19 pozitif olan gebelerin intrapartum ve postpartum dönemde yakın izlemi ve koruyucu ekipmanlar ile doğumun gerçekleştirilmesi gerekmektedir. Intrapartum dönemde mutlaka elektronik fetal monitörizasyon izlemi yapılmalıdır. Kullanılan tüm ekipmanların dezenfeksiyonu, en az sayıda sağlık ekibi ile doğumun gerçekleştirilmesi ve multidisipliner bir yaklaşım ile sürecin yönetilmesi gerekmektedir. Ayrıca yenidoğanın ilk bulguları ve APGAR skoru yakından izlenmeli, enfekte anne ile bebeği arasındaki mesafenin korunmasına özen gösterilmelidir. Yenidoğanın resüsitasyon ihtiyacı belirlenmeli, COVID-19 semptomları incelenmeli ve yoğun bakıma transferine karar verilmelidir. Transfer sırasında kullanılan ekipmanların dezenfeksiyonuna özen gösterilmelidir. Yoğun bakımda izlenen bebeklerin, anne ile birlikte negatif basınçlı odada izole edilmesi önerilmektedir. COVID-19'un emzirmeye engel olmadığı, koruyucu önlemler altında emzirmenin en erken sürede başlatılması gerektiği belirtilmektedir. Taburcu edilen olguların on dört gün izlenmesi önerilmektedir. Virüsün maternal ve neonatal etkileri göz önüne alınarak etkili biçimde yönetilmesi gerekmektedir.

Anahtar kelimeler: COVID-19; pandemi; maternal etkileri; maternal yönetimi; neonatal etkileri; neonatal yönetimi; emzirme; izolasyon.

Sorumlu Yazar*: Gamze Acavut, Ankara Medipol Üniversitesi, Sağlık Bilimleri Fakültesi-Ebelik Bölümü, Ankara, Türkiye 


\begin{abstract}
Coronavirus disease is a respiratory disease caused by the SARS-Cov-2 virus. Rapidly spreading among people, this virus has been declared as a pandemic and threatens the health of the whole world. The virus that can be transmitted by droplets and after contact with contaminated surfaces can be fatal in risk groups. For this reason, pregnant women and newborns are among the groups that should be emphasized sensitively. The anatomical and physiological changes that occur during pregnancy and the immature of the newborn have made it essential to handle the COVID-19 pandemic. Pregnant women who are COVID-19 positive should be monitored closely during the intrapartum and postpartum period, and delivery should be performed with protective equipment. Electronic fetal monitoring must be performed during the intrapartum period. Disinfection of all the equipment used, delivery with the least number of healthcare teams and the process should be managed with a multidisciplinary approach. Besides, the first signs of the newborn and the APGAR score should be closely monitored, and care should be taken to maintain the distance between the infected mother and her baby. The need for resuscitation of the newborn should be determined, the symptoms of COVID-19 should be examined, and its transfer to intensive care should be decided. Care should be taken to disinfect the equipment used during the transfer. It is recommended that babies monitored in intensive care are isolated in a negative pressure room together with the mother. It is stated that COVID-19 does not prevent breastfeeding and breastfeeding should be started as soon as possible under protective measures. It is recommended to monitor the discharged cases for fourteen days. The virus needs to be managed effectively, taking into account maternal and neonatal effects.
\end{abstract}

Key words: COVID-19; pandemic; maternal effects; maternal management; neonatal effects; neonatal management; breastfeeding; isolation

\section{Giriş}

Coronavirüs hastalığı, hayvanları ve insanları enfekte edebilen, insandan insana yayılım gösterebilen bir solunum yolu hastalığıdır $(1,2)$. Insan coronavirüsleri, soğuk algınlığı benzeri hafif semptomlar gösterirken, SARS (Severe Acute Respiratory Syndrome) ve MERS (Middle East Respiratory Syndrome) gibi virüs türevleri daha ağır seyredebilmektedir (1). COVID-19'a neden olan SARS-Cov-2 virüsü ise ilk olarak Çin'de ortaya çıkmış ve hızlı bir yayılım göstererek tüm dünyayı etkilemiştir. COVID-19 ile enfekte kişilerin öksürmesi veya hapşırması ile oluşan damlacıkların insandan insana bulaşması ile yayılım gerçekleşmektedir (2).

COVID-19 virüsü asemptomatik seyredebildiği gibi şiddetli akut solunum yolu semptomlarına yol açabilmektedir (3). Semptomlar arasında sıklıkla ateş, kuru öksürük, nefes almada güçlük ve nefes darlığı yer almaktadır. Bazı vakalarda daha az olmakla birlikte konjonktivit, yorgunluk, baş ağrısı, bulantı/kusma ve diyare gibi semptomlar görülebilmektedir $(3,4)$. Şiddetli seyreden vakalarda ise pnömoni, akciğer yetmezliği ve ölüm görüldüğü belirtilmektedir $(1,2)$. Hastalığa ilişkin semptomların ortaya çıkışı, virüse maruziyetten sonraki 2-14 günü kapsamaktadır $(2,5)$.

Tüm yaş grupları COVID-19 açısından risk altında olmasına rağmen bazı gruplar yüksek riskli olarak kabul edilmektedir.
Özellikle ileri yaşta olanlar ve kronik hastalığı bulunanlar (diyabetes mellitus, hipertansiyon, HIV, kalp hastalıkları vb.) riskli gruplardır $(4,6)$. Dünya Sağlık Örgütü (DSÖ) ve UNFPA (Birleşmiş Milletler Nüfus Fonu) bu gruplar dışında, gebelerin veya doğum yapan kadınların COVID-19 enfeksiyonu açısından yüksek risk grubunda olmadıklarını belirtmektedir. Ancak gebelik döneminde ve postpartum dönemde meydana gelen fizyolojik değişiklikler nedeniyle (bağışıklık, oksijen ihtiyacında artış vb.) komplikasyon riski artmaktadır. Anatomik değişiklikler, torasik kavitedeki değişiklikler ve diyaframın yükselmesi hipoksiye olan maternal toleransı azaltmaktadır $(4,6,7)$. Bu nedenle maternal açıdan gebelik, doğum ve doğum sonu döneme ilişkin hassasiyet gösterilmesi ve pandemi açısından gerekli önlemlerin alınması önemlidir (6-8). COVID-19'un vertikal geçişine ve konjenital enfeksiyona yol açtığına ilişkin verilerin kısıtlı olduğu belirtilmektedir (9-12). Fetüsün ve yenidoğanın COVID-19 enfeksiyonuna karşı duyarlı olduğunu gösteren veriler sınırlıdır. Ancak doğuştan gelen bağışıklık fonksiyonlarının immatür olması bu grubu enfeksiyona karşı duyarlı hale getirmektedir $(7,10)$. Bu nedenle maternal-neonatal değerlendirme, fetüs ve yenidoğana yönelik önlemlerin alınması ve bölümler arasında entegre bir yaklaşımın benimsenmesi önemlidir $(6,13,14)$. Sağlık 
ekibinin konu ile ilgili güncel bilgiye ve önerilere erişebilmesi enfeksiyon ile mücadelede etkili olacaktır. Bu nedenle COVID19'un maternal ve neonatal açıdan etkilerinin belirlenmesi ve yönetilebilmesi amacıyla literatür bilgileri derlenmiştir.

\section{COVID-19'un Maternal Etkileri}

Gebelikte COVID-19 enfeksiyonu ile ilgili sınırlı sayıda vaka olduğu ve bunların büyük bölümünün ciddi bir komplikasyon olmadan taburcu edildiği belirtilmektedir $(9,15)$. Yapılan bir sistematik incelemede 108 gebenin yer aldığı vakalara yer verilmiştir. Bu gebelerin yaş ortalaması 29-32 ve büyük bölümünün üçüncü trimesterde olduğu belirlenmiştir. Erken gebelik haftasında başvuran gebeler komplikasyon olmadan taburcu edilmiştir. Preeklampsi, gestasyonel diyabet, hipotroidi ve plasental problemler gibi komorbiditeler nedeniyle hastaneye başvuran gebeler olduğu belirtilmiştir. Olguların \%92'si sezaryen doğum ile sonuçlanmış ve endikasyon olarak büyük ölçüde fetal distres gösterilmiştir (7). Maternal pnömoni ile ilişkili olarak erken membran rüptürü, preterm eylem ve intrauterin fetal ölüm görülebildiği belirtilmektedir (16). Dokuz gebelik bir olgu serisinde dört hastanın preterm eylem gerçekleştirdiği ifade edilmiştir (17). COVID-19 enfekte gebelerde sıklıkla yüksek ateş ve kuru öksürük klinik belirti olarak ortaya çıkmaktadır. Bunların yanı sıra halsizlik, dispne ve diyare diğer belirtilerdendir (7). Çin'de dokuz gebenin yer aldığı çalışmada dört kişide öksürük, üçünde miyalji, ikisinde boğaz ağrısı ve halsizlik belirtileri görülmüştür. Ayrıca üç hastada aminotransferaz konsantrasyonunda artış, beş hastada lenfositopeni olduğu belirlenmiştir (17). Ayrıca bazı olgularda yüksek C-reaktif protein konsantrasyonu görülmüştür $(7,17)$.

Gebelik olgularının yer aldığı bir derlemede üç gebenin yoğun bakım ünitesine alındığı ancak hiç ölüm gerçekleşmediği ifade edilmektedir (7). Yine İran ve Çin'i kapsayan, COVID-19 ile enfekte otuz bir gebenin yer aldığı bir sistematik incelemede iki annenin solunum komplikasyonlarına bağlı olarak öldüğü belirtilmektedir (16). Çin'de dokuz olgunun yer aldığı çalışmada hiç pnömoni ve ölüm olmadığı, tümünün canlı doğum gerçekleştirdikleri belirtilmiştir (17).

COVID-19'un klinik bulguları ve maternal etkileri göz önüne alındığında intrapartum ve postpartum dönemin etkili biçimde yönetilmesi büyük önem kazanmaktadır.

\section{3. İntrapartum ve Postpartum Dönem ve Yönetimi}

COVID-19'un gebeler üzerine olan yönetimi MERS veya SARS'ın etkileri ile kıyaslanarak ya da şu an mevcut veriler ışığında enfekte ancak gebe olmayan birine benzer klinik tablo göstermesi üzerine kurulu yaklaşımlar şeklindedir. Fakat gebelik sürecindeki değişimler doğrultusunda daha multidisipliner bir yaklaşım izlenmesi önerilmektedir $(6-8,18)$.

3.1. Intrapartum dönemde yönetim: COVID-19 gibi pandemi boyutuna ulaşan enfeksiyon hastalıklarında öncelik tedaviden çok, korunma olması nedeniyle sağlık personeli, gebe ve yenidoğanın koruyucu önlemleri alınmalıdır. Bu konuda sağlık kuruluşlarında genelde poliklinik ve acil servis başvurularında uygulanan triajın, doğumhane gebe kabulünde de yapılması önerilmektedir. Gebenin semptomlarından şüphelenildiği durumlarda mümkünse negatif basınçlı bir odada izole edilmesi önerilmektedir. Bunun mümkün olmadığı durumlarda tek başına izlem yapmaya elverişli bir odada, doğumhaneye kabul edilmeden önce triaj yapılmalıdır (19). COVID-19 pozitif gebenin takibi ve doğumu mümkünse negatif basınçlı odalarda, değilse izole etmeyi sağlayan tek kişilik odalarda gerçekleştirilmelidir. Sağlık personeli triajın yapılamadığı acil olgularda; gebenin temaslı, olası pozitif hasta olup olmadığına bakmaksızın maske, gözlük, önlük, eldiven, siperlik gibi kişisel koruyucu ekipmanları eksiksiz kullanmalıdır. Aerosol bulaşın en sık bulaş yolu olduğu düşünüldüğünde gebenin maske kullanması, tanılı hastalarda ise personelin N95 maske kullanması önerilmektedir (20). COVID-19 virüsünün bazı yüzeylerde 24-72 saat yaşayabildiğini gösteren bulgular nedeniyle, özellikle gebe ile teması olan tıbbı cihazların ve yüzeylerin hijyenine özen gösterilmelidir (21). COVID-19 tanısı almış gebelerin doğum eylemi sırasında yapılacak takibinde, yönetimi etkileyecek en önemli parametrelerden biri maternal hipoksidir. Buna yönelik olarak gebenin yaşamsal bulgularının ölçümlerine ek olarak oksijen saturasyonu ve solunum sayısı yakından izlenmelidir. Bu parametreleri içeren MEOWS (Modifiye Erken Obstetrik Uyarı Skorlaması) skorlaması takip sırasında kullanılabilir. İzlemde oksijen saturasyonu \%95 ve üzerinde, solunum hızı dakikada 20 ve altında, ateş $38.5^{\circ} \mathrm{C}$ 'nin altında olmalıdır. Fetal etkilerin izlenmesi amacıyla Non-Stres Test (NST) takibi dikkatli biçimde yapılmalı, uteroplasental oksijenizasyonu daha iyi sağlaması nedeniyle gebe sol lateralde dekubit pozisyonunda takip edilmelidir (22).

COVID-19 pandemisinde sınırlı verilerle gösterilmekle birlikte genel olarak viral enfeksiyonların etkilerinden biri gebeliğin son trimesterinde preterm eylemdir. Preterm eyleme yönelik olarak, COVID-19 tanılı gebelerde kullanılacak tokoliz ajanlarının etkinliği ve olası yan etkileri ile ilgili çalışmalar devam etmekte olup, çelişkili sonuçlar da mevcuttur. Fakat COVID-19 pozitif gebe preterm eylem nedeniyle doğumhaneye kabul edildiğinde özellikle fetal akciğer maturasyonu için steroid kullanımı sonrası zaman kazanmak amaçlı tokoliz uygulanmaması konusunda görüş birliği mevcuttur 
(23). Bazı çalışmalar steroid kullanımını, yoğun bakım olgularında uygulanan kortikosteroidlerin genel etkilerini göz önünde bulundurarak önermemektedir. Ancak yapılan antenatal steroidin betametazon olması, yoğun bakım olgularında uygulanan dozun 1/15-1/80'i arasında olması ve tek doz uygulanması nedeniyle kullanımını öneren çalışmalar mevcuttur (24).

3.1.1. Doğum şekli: Doğum şekline gebenin takipleri ve maternal-fetal etkiler göz önünde bulundurularak ve obstetrik endikasyonlara göre multidisipliner bir yaklaşımla karar verilmeli, kararlar hastaya özgü olmalıdır (25). Fetal strese yol açtığı düşünülen durumlarda sezaryen doğum endikasyonu konusunda daha esnek karar verilebileceği belirtilmektedir (23). Vajinal doğum ile ilgili özellikle vertikal geçiş ve vücut sıvılarından bulaş olabileceğine yönelik şüpheler mevcuttur. Yapılan çalışmalar sonucunda kanıtlanmış vertikal geçiş olmaması nedeniyle olası veya tanılanmış COVID-19 gebelerde vajinal doğum kontrendike değildir (22). Ancak yeterli kanıt olmaması nedeniyle sezaryen ile doğum tercih edilebilmektedir $(6,11-13)$. Vajinal doğum sırasında gebenin maske kullanımı, ikinci evrede etkin ıkınmayı olumsuz etkileyeceğinden sağlık personelinin tüm koruyucu ekipmanları kullanması gerekmektedir. Saturasyonun \%95 ve üzerinde olması sağlanmalı, gerekliyse oksijen desteği verilmelidir. Saturasyonu düşük olan gebelerde olası pulmoner ödeme yönelik olarak hidrasyon desteği kontrollü yapılmalı ve bolus uygulamalardan uzak durulmalıdır (26). Doğum indüksiyonu amacıyla dinoprost veya oksitosin kullanımında bir kısıtlamama olmamakla beraber kritik olgularda aşırı sıvı yüklemesi ve kardiyovasküler dekompansasyon riski nedeniyle yüksek doz veya bolus şeklinde oksitosin kullanımından kaçınılmalıdır (22). Erken membran rüptürü nedeniyle eylem takibine alınan gebelerde veya eylem sırasında membranların açılması durumunda Penisilin G veya Ampisilin profilaksisi rutinde kullanılabilmektedir. Ayrıca sekonder bakteriyal pnömonide profilaksi amaçlı Seftriakson tercih edilebilir (27). Intrapartum dönemde trombositopeni yoksa, ağrılarla oluşacak hiperventilasyonu önlemek ve acil sezaryen gerektiğinde genel anestezi uygulama ihtiyacını azaltmak amacıyla epidural anestezi önerilmektedir (28). Eylemin ikinci evresinde aktif ıkınmanın maske takılı durumda zor olması, bu süreçte aerosol partiküllerin doğumhane personeline bulaşma riskinin artabileceği göz önüne alınarak ikinci evreyi kısaltılmak için müdahaleli vajinal doğum düşünülebilir (23). Postpartum dönemde rutin prosedürler uygulanmalı, yaşam bulguları yakından izlenmeli ve dikkatli biçimde kanama kontrolü sağlanmalıdır. Kanama kontrolünde uterotonik olarak uygun doz ve sürede uygulanmak üzere oksitosin tercih edilebilir. Misoprostol, prostoglandin E2 ve karbetosin tercih edilmekle birlikte, hemostaz sağlamak için traneksamik asit tercih edilebilir. Bildirilen akut solunum yetmezliği vakaları nedeniyle metilergometrin kullanımının tercih edilmemesi öneriler arasındadır (29). Maternal hipoksi nedeniyle oluşan fetal sıkıntı ve artan yoğun bakım takip ihtiyacı nedeniyle COVID-19 tanılı gebelerde sezaryen doğum oranlarının yüksek olduğu belirlenmiştir (25). Sezaryen doğum gerçekleştirilecek olgularda (acil veya elektif), şüpheli veya pozitif hastalar için önceden belirlenmiş negatif basınçlı ya da HEPA filtreli odalarda doğum gerçekleştirilmelidir. Anestezi, cerrahi ve yenidoğan ekibi uygun koruyucu ekipmanları kullanmalıdır. Ayrıca genel anestezi uygulanacak vakalarda orofarengeal bölgeye müdahalede bulunan personelin N95 maske ve siperlik kullanımı konusunda özenli olması gerekmektedir (30). Sezaryen doğumda, trombositopeni yoksa anestezi uygulamasının rejyonel anestezi şeklinde yapılması önerilmektedir. Fakat bazı vakalarda hızlı hipotansiyon gelişebildiğinden uygulama sürecinde dikkatli olunmalıdır (31). Genel anestezi uygulamasından mümkün olduğunca kaçınılması, maternal solunum fonksiyonlarının bozulması veya acil sezaryen doğum söz konusu olduğunda tercih edilmesi önerilmektedir. Bu durumda personelin kişisel koruyucu önlemleri almasına ek olarak yüz maskesi ile solunum devresi arasına filtre yerleştirilmesi ve video-laringoskopi kullanımı tavsiye edilmektedir. Sezaryen sonrası anne ve bebeğe yönelik uygulamalar ve yapılması gerekenler vajinal doğum sonrası uygulamalarla benzer niteliktedir (28).

3.2. Postpartum dönemde yönetim: Doğum sonrası hastaların değerlendirilmesi multidisipliner bir ekip tarafından yapılmalıdır. Yoğun bakım ihtiyacı, COVID-19'a yönelik uygulanacak medikal tedavi gerekliliği ve uygun tedavi protokolüne karar verilmelidir. Postpartum takip sürecinde hastaların analjezi ihtiyacına yönelik NSAID uygulamasına yönelik farklı yaklaşımlar mevcuttur. Erken dönemde yapılan çalışmalar uygulanmaması gerektiğini belirtmekte, güncel çalışmalar uygulanmasına engel olmadığını ifade etmektedir. Opioid analjeziklerden olası solunum depresyonu etkisi nedeniyle kaçınılması önerilmektedir (32). COVID-19'a bağlı olarak tromboemboli riski nedeniyle doğum sonrası profilaktik antikoagülan tedavi kullanılabileceği belirtilmektedir (33).

\section{COVID-19'un Neonatal Etkileri}

COVID-19'un dünyadaki yayılım hızıyla ilişkili olarak yenidoğanlarda virüsün görülme sıklığının arttığı ancak verilerin sınırlı olduğu belirtilmektedir (13). Ayrıca maternal COVID-19 enfeksiyonunun vertikal geçişine ilişkin veriler de 
kısıtlıdır. Yapılan araştırmalarda maternal pnömoni ile ilişkil olarak intrauterin gelişme geriliği, intrauterin fetal ölüm ve neonatal mortalite olabilmektedir $(11,16)$. Sınırlı olan veriler doğrultusunda bir olguda vertikal geçiş olduğu, bir olguda intrauterin ölüm gerçekleştiği belirtilmektedir (7). Ayrıca COVID-19 pozitif annelerin bazılarında preterm eylem görülebildiği ancak bunların enfeksiyon ile ilişkisinin açık olmadığı ifade edilmektedir (34).

Çin'de retrospektif bir çalışmada iki vakada fetal distres görülmüştür. Canlı doğum ile sonuçlanan bu olgularda neonatal asfiksiye rastlanmamıştır. Birinci dakika APGAR skorları 8-9, 5. dakika skorları 9-10 olarak belirlenmiştir. Aynı olgulardan bir yenidoğanın myokard enzimlerinde hafif bir artış olduğu ancak herhangi bir semptom görülmediği belirtilmiştir (17). Yine retrospektif bir çalışmada COVID-19 testi pozitif olan on altı gebe ile negatif olan kırk beş gebenin sezaryen sonrası neonatal sonuçları incelenmiş; fetal distres, mekonyumlu amniyotik mayi ve neonatal asfiksi açısından anlamlı bir farklılık olmadığı belirlenmiştir (35). COVID-19 enfekte annelerin doğum sonuçlarına bakıldığında sınırlı sayıda olguya dayanarak; yenidoğanlarda başlangıç semptomları olarak solunum sıkıntısı, siyanoz, taşikardi, ateş, beslenme intoleransı ve kusma görüldüğü belirtilmektedir $(7,13)$. İran'da 15 günlük neonatal bir olgu ateş ve letarji semptomları ile kliniğe kabul edilmiş ve öksürük ve gastrointestinal herhangi bir bulgu gözlenmediği belirtilmiştir. Bu olguda taşikardi, taşipne, hafif subkostal retraksiyon görülmüş ve oksijen saturasyonunun \%93 olduğu belirlenmiştir (14). Genel anlamda yenidoğanda görülen bu semptomların sıklıkla hafif seyrettiği, ancak bir olguda multipl organ yetmezliği ve DIC (yaygın damar içi pıhtılaşma) nedeniyle neonatal ölüm gerçekleştiği belirtilmektedir $(7,13)$. Literatürde SARS-CoV-2 IgM antikorları yüksek olan üç yenidoğanın boğaz sürüntü örneklerinde pozitif bulguya rastlanmadığını gösteren olgular da yer almaktadır (36). Virüsün anne sütü ile geçip geçmediğine yönelik kanıt olmadığı, emzirme sırasında damlacık yoluyla yenidoğana bulaşabileceği ifade edilmektedir $(16,37)$.

COVID-19'un klinik bulguları ve neonatal etkileri göz önüne alındığında bu dönemin ve semptomların etkili biçimde yönetilmesi büyük önem kazanmaktadır.

\section{Neonatal Dönem ve Yönetimi}

COVID-19'un yönetimi gebelik sürecinde, doğum sırasında ve doğum sonrasında olmak üzere üç aşamada ele alınmalıdır.

5.1. Gebelik süreci: Özellikle gebelik sürecindeki fizyolojik ve anatomik değişikliklerle ilişkili olarak virüse hassasiyet gelişebilmektedir. Gebeliğin son trimesterinde klinik bulgular görüldüğünde COVID-19 şüphesi ile yaklaşılmalıdır. Annenin pozitif olduğu durumlarda uygulanan tedavi yaklaşımları multidisipliner olarak ele alınmalıdır. Uygulanan tedavinin fetal açıdan etkileri göz önüne alınmalı ve doğuma yönelik olarak neonatal hazırlıklar yapılmalıdır. Yenidoğanın ilk müdahalesini yapacak gerekli ekipmanlar hazırlanmalı, fiziksel koşulların izolasyona uygun biçimde hazırlanması sağlanmalıdır. Ayrıca anne pozitif olgularda yenidoğana mutlaka şüpheli yaklaşılmalıdır $(10,13,37)$.

5.2. Doğum süreci: Doğuma yönelik neonatal yönetim, öncelikle doğum kararının doğru biçimde alınması ile başlamalıdır. Doğum eylemine yönelik adımlar atılırken neonatolog, perinatolog ve anesteziyolog iş birliği sağlanmalı, hemşire ve ebelerin bu süreçteki tüm uygulamalarında multidisipliner bir yaklaşım benimsenmelidir (13). Elektronik fetal monitorizasyon yapılmalı ve fetal kalp atımları yakından izlenmelidir (38). Fetal akciğer maturasyonu sağlamak amacıyla steroid kullanımının COVID-19 açısından risk oluşturduğunu gösteren kanıt olmadı̆̆ından, preterm doğum olgularında gerektiğinde steroid verilebilmektedir. COVID-19 testi pozitif olan olgularda maruziyeti en aza indirgemek amacıyla az sayıda personel ile doğumun gerçekleştirilmelidir $(6,39)$. Doğum şekli ve zamanı konusunda UNFPA endikasyon ve annenin doğum tercihi göz önüne alınarak karar verilmesini önermektedir $(6,37)$. Üçüncü trimesterde negatif bir test sonucuna ulaşana kadar neonatal bir engel yoksa ve mümkünse doğum ertelenmelidir (34). Doğum, izole negatif basınç özelliği bulunan bir alanda gerçekleştirilmeli ve tüm koruyucu ekipmanların kullanımı sağlanmalıdır $(13,37)$. Tüm müdahalelerden önce eller su ve sabun ile yıkanmalıdır. Şüpheli ve pozitif anne varlığında yenidoğanın resüsitasyon ihtiyacı belirlenmeli, APGAR skorları dikkatlice değerlendirilmeli, saturasyon ve vital bulgular yakından izlenmelidir. Doğumda, yenidoğanın termoregülasyonu sağlandıktan sonra yıkanması, kurulanması önerilmekte ve hasta anne ile yenidoğanı geçici süre ayrı tutmak ve izole etmek gerekmektedir $(13,37,39)$. Doğum masası ile radyant ısıtıcı arasında en az iki metre mesafe olmalıdır. Neonatal resüsitasyon gerektiğinde en az sayıda sağlık çalışanı ile N95 maske dahil tüm koruyucu ekipmanlar kullanılarak müdahale gerçekleştirilmelidir (37). Kord klempleme süresine ilişkin herhangi bir kanıt olmamakla birlikte, vertikal geçişin göz ardı edilmemesi ve kordun vakit kaybetmeden klemplenmesi önerilmektedir. Ayrıca ten tene temasın engellenmesi diğer öneriler arasındadır $(13,37)$. COVID-19 testi pozitif annelerin bebeklerine, doğum sonrası 2448 saatte test yapılması gerektiği belirtilmektedir (10). 
5.3. Doğum sonrası dönem: Yenidoğanın genel durumu stabil ise, damlacık izolasyon önlemleri alınarak anne ile birlikte aynı odada olacak biçimde servise transfer edilmesinde sakınca olmadığı belirtilmektedir. Bu durumda beş gün boyunca hemşire/ ebelerin gözetiminde tutulması ve sonrasında en erken sürede evde izolasyonun sağlanarak taburculuğun gerçekleştirilmesi önerilmektedir. Yenidoğanın resüsitasyon ihtiyacı varsa, ventilasyon sağlandıktan sonra tekrar değerlendirilerek yoğun bakım ya da özel bakım ihtiyacı belirlenmelidir. Yoğun/özel bakım ihtiyacı olmayanların stabilizasyon sonrasında anneleri ile birlikte serviste izole edilebileceği belirtilmektedir $(10,14$, $37,39)$. Anne ve bebeği rutin olarak izole etme ve birbirlerinden ayırma uygulamasından kaçınılması ve emzirmenin uygun biçimde başlatılması gerektiği vurgulanmaktadır (40).

\subsection{Yoğun bakıma transfer kararı verilen yenidoğan: $\mathrm{Bu}$} süreçte ebeveynleri ile temasının önlenmesi, temas ve damlacık izolasyon önlemleri altında ilgili üniteye transferinin gerçekleştirilmesi önerilmektedir $(10,14,37,39)$. Transfer sırasında yenidoğanın mutlaka transport küvöz ile taşınmasına, ambulans kullanımı gereken durumlarda ise ventilatör, monitör ve taşıma ekipmanlarının bulundurulmasına özen gösterilmelidir. Görevli sağlık ekibinin bu süreçte koruyucu ekipmanları eksiksiz kullanması ve transfer öncesindesonrasında küvöz, ambulans ve diğer ekipmanların mutlaka dezenfeksiyonu sağlanmalıdır (13). COVID-19 ile enfekte ya da şüpheli yenidoğanın yoğun bakıma kabulü sırasında sorumlu ekip üyeleri koordinasyonu sağlamalıdır. Hasta kabul edilirken koruyucu ekipman kullanılmalı ve aksesuar kullanmaktan kaçınılmalıdır. Ayrıca kullanılan ekipmanları, giysileri ve diğer eşyaları yoğun bakım dışında kullanmamaya özen gösterilmelidir (13). Servise alınan yenidoğan mümkünse negatif basınçlı odada izole edilmeli, değilse ayrı bir odaya alınmalıdır (14, 37, 39). Yoğun bakım ünitesinde kullanılan ekipmanların hastalar ve servisler arasında yer değiştirmesi kısıtlanmalıdır. Kullanılan tüm malzemeler, cihazlar (USG, EKG cihazı vb), küvözler hastadan hastaya geçmeden önce dezenfeksiyon işleminden geçirilmelidir. Tüm invaziv işlemlerden ve numune almadan önce el yıkama ve N95 maske kullanımına özen gösterilmelidir. Alınan numuneler özenle ve doğru biçimde etiketlenmeli, saklanmalı ve koruyucu önlemler altında laboratuvara transfer edilmelidir (13). Tedavi planlaması neonatalog, pediatrist, hemşire, dezenfeksiyon personeli ve diğer sağlık ekibi üyeleri ile multidisipliner bir yaklaşım içerisinde yapılmalıdır. Oksijen tedavisi, sıvı replasman tedavisi, antibiyoterapi, enteral/ parenteral beslenme desteği, sürfaktan ve nitrik oksit uygulaması, mekanik ventilasyon gibi tedavi yaklaşımları tercih edilebilmektedir. Ancak COVID-19'a ilişkin etkili bir tedavi yöntemi henüz bulunmamaktadır. Bu nedenle semptomatik ve olgu bazında tedavi uygulamalarının benimsenmesi ve geniş spektrumlu antibiyotiklerin gereksiz kullanımından kaçınılması önerilmektedir (13). Antiviral tedavi yaklaşımına ilişkin olarak klorokin, hidroksiklorokin, kortikosteroid veya intravenöz gama globülin gibi ilaçların karşılaştırılmasına yönelik yeterli klinik çalışma henüz bulunmamaktadır. Enfekte olgularda henüz klorokin/hidroksiklorokin kullanılan neonatal vaka bulunmadığı, destekleyici tedavi yaklaşımının uygulandığı belirtilmektedir (37). Yoğun bakım ünitesinde izlenen yenidoğanların ebeveynleri COVID-19 pozitif ise yoğun bakıma girmelerine müsaade edilmemelidir. Eğer yenidoğanda COVID-19 pozitif ise anne ve bebek izole edilmeli ve ziyaretçi kısıtlaması yapılmalıdır. Bu izolasyon negatif basınçlı bir odada olmalı ve annenin eldiven, maske, gözlük kullanması sağlanmalıdır. Eğer anne ve bebeğin ayrı kalması gerekli ise bu durum aileye açıklanmalı, sosyal ve ruhsal destek unsurları sürece dahil edilmelidir $(14,37)$. COVID-19 pozitif olan ve yoğun bakımda izlenen yenidoğanlarda taburculuk öncesi testlerin negatifliği doğrulanmalı ve ebeveynler konuya ilişkin olarak eğitilmelidir. Taburculuk sonrasında evde izolasyon devam ettirilmeli ve aileye temas izolasyonuna ilişkin bilgilendirme yapılmalıdır (14). Bulaş riski olan yenidoğanların taburculuk sonrası 14 günlük sürede telefon, yüz yüze görüşme gibi yöntemler ile yakından izlenmesi önerilmektedir (10). Ayrıca 14 gün sonra yenidoğandan kontrol amaçlı farengeal sürüntü örneği alınmalı ve sonuç negatif gelirse 28. günde izlem sonlandırılmalıdır (40).

5.5. Emzirme: Virüsün anne sütü ile geçişine ilişkin veri olmadığı ve damlacık yoluyla bulaşması nedeniyle koruyucu önlemler altında emzirmenin sürdürülmesi tavsiye edilmektedir. Yapılan araştırmalarda enfekte annelerin sütünde virüse rastlanmadığı ve anne sütünün yenidoğan için antikor kaynağı olması nedeniyle emzirmenin teşvik edilmesi ve en kısa sürede başlatılması önerilmektedir (10, 34, 37). Çin'de COVID-19 pozitif annelerin emzirmelerine tercihen donör süt kullanımı veya formül kullanımını öneren yaklaşımlar yer almakla birlikte bu görüşü destekleyen kanıtlara ulaşılamamıştır. Bu nedenle WHO (Dünya Sağlık Örgütü), CDC (Hastalık Kontrol Önleme Merkezi) ve RCOG (Royal College of Obstetricians and Gynecologists) emzirmeyi desteklemektedir. Ayrıca anne sütünün pastörize edilmesinden kaçınılması gerektiği ifade edilmektedir (40). Emzirme sırasında annenin el hijyeninin ve eldiven, maske, gözlük/siperlik kullanmasının önemli olduğu belirtilmektedir. 
Eğer anne sütü pompa ya da elle sağılacaksa el yıkama ve süt saklama konusunda hassas olunması tavsiye edilmektedir. Süt sağma aparatlarının her kullanım sonrasında sıcak su ve sabun ile dezenfeksiyonu yapılmalıdır. Ayrıca ebeveynlere bulaş ve koruyucu önlemler konusunda bilgilendirme yapılmalıdır (10, $34,37,39)$. Annenin COVID-19 testi pozitif olduğu durumlarda semptomlar ve maternal tedavi yaklaşımları doğrultusunda izolasyon yaklaşımları izlenmelidir. Annede şiddetli solunum yolu semptomları ve ateş mevcut ise geçici süre ile anne ve bebek ayrılmalı ancak hijyenik koşullarda süt sağma yoluyla beslenmenin sürdürülmesi sağlanmalıdır (40).

5.6. Ziyaretçi uygulaması: Anne ve yenidoğan için hastanede kaldıkları süreçte tek bir ziyaretçi olması ve ziyaretçinin servise alınmadan önce COVID-19 semptomları açısından değerlendirilmesi önerilmektedir. Ayrıca ziyaret öncesi ellerin temizliği, koruyucu önlük, maske kullanımı ve oda içerisinde temas kurallarına uyulmasının önemi vurgulanmaktadır (39).

\section{Sonuç}

Maternal ve neonatal olgularda COVID-19 pozitif veya şüpheli pozitif durumlarda anne, bebek ve sağlık ekibini koruyucu yaklaşımlar benimsenmelidir. Maske, eldiven, gözlük ve önlük gibi koruyucu ekipman kullanımının yanı sıra etkili izolasyon önlemleri alınmalıdır. Doğum eylemi negatif basınçlı izole odalarda ve en az sayıda sağlık personeli ile gerçekleştirilmelidir. Doğum ve doğum sonu dönemde anne ve bebeği mümkün oldukça birlikte izole etmek, buna uygun fiziki koşulları sağlamak, semptomların seyrine göre emzirmeyi başlatmak ve sürdürmek gerekmektedir. Tüm aşamalarda multidisipliner olarak perinatolog, neonatolog, mikrobiyolog, hemşire, ebe, radyolog ve diğer sağlık çalışanlarını kapsayan bir ekip oluşturulmalıdır. Bu ekip üyelerinin izolasyon eğitimleri güncellenmeli ve kişisel koruyucu ekipmanlar tedarik edilmelidir. Tedavi yaklaşımları belirlenirken öncelikle semptomatik ve destekleyici tedavi adımları izlenmelidir. Bu süreçte kullanılan tüm araç-gereç ve tıbbi ekipmanların dezenfeksiyonu sağlanmalıdır. Ayrıca bireyler hastaneye kabul sürecinden başlayarak, taburculuk ve evde izlem sürecine kadar tüm aşamalarda anne, baba ve diğer bakım verenler koruyucu yaklaşımlara, izolasyona, hijyene ve temas kurmaya ilişkin eğitilmelidir. Ayrıca taburculuk sonrası evde izlem sürecinde sağlık ekibinin yakın izlem yapması gerekmektedir.

Çıkar çatışması: Bu yazı tamamen bilimsel amaçla yazıımış olup, yazarların bu yazı ile herhangi bir çıkar çatışması bulunmamaktadır. Çalışmayı maddi olarak destekleyen kişi/kuruluş yoktur.

\section{Kaynaklar}

1. World Health Organization. Coronavirus disease (COVID-19) outbreak: rights, roles and responsibilities of health workers, including key consideratıons for occupational safety and health. March 18, 2020. Available from: https://www.who.int/ publications-detail/coronavirus-disease-(covid-19)-outbreakrights-roles-and-responsibilities-of-health-workers-including-keyconsiderations-for-occupational-safety-and-health. (Erişim tarihi: 10 Haziran 2020)

2. Centers for Disease Control and Prevention. What law enforcement personnel need to know about coronavirus disease 2019 (COVID-19). March 2020. Available from: https://www. cdc.gov/coronavirus/2019-ncov/community/guidance-lawenforcement.html. (Erişim tarihi: 10 Haziran 2020)

3. Özdemir Ö. Coronavirus Disease 2019 (COVID-19): Diagnosis and management. Erciyes Med J 2020; 42:242-247.

4. Aghdam MK, Jafari N, Eftekhari K. Novel coronavirus in a 15-dayold neonate with clinical signs of sepsis, a case report. Infect Dis (Lond) 2020; 52:427-429.

5. World Health Organization. Global Surveillance for COVID-19 caused by human Infection with COVID-19 Virus. Interim Guidance March 20, 2020. Available from: https://www.who.int/ publications-detail/global-surveillance-for-covid-19-caused-byhuman-infection-with-covid-19-virus-interim-guidance. (Erişim tarihi: 10 Haziran 2020)

6. United Nations Population Fund. COVID-19 Technical Brief for Maternity Services April 2020. Available from: https://www. unfpa.org/sites/default/files/resource-pdf/COVID-19_MNH_ guidance_04.pdf . (Erişim tarihi: 10 Haziran 2020)

7. Zaigham M, Andersson O. Maternal and perinatal outcomes with COVID-19: A systematic review of 108 pregnancies. Acta Obstet Gynecol Scand 2020; 99:823-829.

8. United Nations Population Fund. Coronavirus Disease (COVID-19) Preparedness and Response-UNFPA Interim Technical Brief, Sexual and Reproductive Health and Rights, Maternal and Newborn Health \& COVID-19. March 23, 2020. Available from: https:// www.unfpa.org/sites/default/files/resource-pdf/COVID-19_ Preparedness_and_Response-_UNFPA_Interim_Technical_ Briefs_Maternal_and_Newborn_Health_-23_March_2020_.pdf . (Erişim tarihi: 10 Haziran 2020)

9. Maternal, Fetal Tıp ve Perinatoloji Derneği. Gebelikte Coronavirus Enfeksiyonu (COVID-19) Hakkında Görüş (3. Bilgilendirme, 03.04.2020). Available from: http://www.tmftp.org/files/ Duyurular/3.bilgilendirme.pdf. (Erişim tarihi: 10 Haziran 2020) 
10. Puopolo KM, Hudak ML, Kimberlin DW, Cummings J. Initial Guidance: Management of Infants Born to Mothers with COVID-19. American Academy of Pediatrics Committee on Fetus and Newborn, Section on Neonatal Perinatal Medicine, and Committee on Infectious Diseases. 2020. Available from: https://www.sigo. it/comunicati-covid-19/initial-guidance-management-of-infantsborn-to-mothers-with-covid-19/. (Erişim tarihi: 10 Haziran 2020)

11. Luo Y, Yin K. Management of pregnant women infected with COVID-19. Lancet Infect Dis 2020; 20:513-514.

12. Ma X, Zhu J, Du L. Neonatal management during Coronavirus disease (COVID-19) outbreak: The Chinese experiences. Neoreviews 2020; 21:e293-e297.

13. Erdeve Ö, Çetinkaya M, Baş AY, et al. The Turkish Neonatal Society proposal for the management of COVID-19 in the neonatal intensive care unit. Turk Pediatri Ars 2020; 55:86-92.

14. Government of Western Australia Department of Health, COVID-19 Guidance for Neonatal Services. 2020. Available from: https://www. healthywa.wa.gov.au/-/media/Files/Corporate/general-documents/ Infectious-diseases/PDF/Coronavirus/COVID-19-Guidlines-forNeonatal-Services.ashx. (Erişim tarihi: 10 Haziran 2020)

15. John Hopkins. COVID-19, Maternal and Child Health, NutritionLiterature Repository April, 2020. Available from: https:// resourcecentre.savethechildren.net/node/17503/pdf/covid-19_ maternal_and_child_health_nutrition_-_literature_repository_ april_2020.pdf. (Erişim tarihi: 22 Mayıs 2020)

16. Karimi-Zarchi $M$, Neamatzadeh $H$, Dastgheib SA, et al. Vertical Transmission of Coronavirus Disease 19 (COVID-19) from Infected Pregnant Mothers to Neonates: A Review. Fetal Pediatr Pathol 2020; 39:246-250.

17. Chen H, Guo J, Wang C, et al. Clinical characteristics and intrauterine vertical transmission potential of COVID-19 infection in nine pregnant women: a retrospective review of medical records. Lancet 2020; 395(10226):809-815.

18. Yeşilçınar I, Kıncı MF. COVID-19 Pandemisinde Doğumun İntrapartum ve Postpartum Yönetimi. Ege Klinikleri Tıp Dergisi 2020; 58:46-48.

19. National Health Commission of the People's Republic of China. Diagnosis and treatment guideline for COVID-19 infection (trial version 6). 2020. Available from: http://www.kankyokansen.org/uploads/ uploads/files/jsipc/protocol_V6.pdf. (Erişim tarihi: 22 Mayıs 2020)

20. Centers for Disease Control and Prevention. Healthcare Infection Prevention and Control FAQs for COVID-19. May 29, 2020. Available from: https://www.cdc.gov/coronavirus/2019-ncov/ hcp/infection-control-faq.html. (Erişim tarihi: 22 Mayıs 2020)
21. Van Doremalen N, Bushmaker T, Morris DH, et al. Aerosol and Surface Stability of SARS-CoV-2 as Compared with SARS-CoV-1. N Engl J Med 2020; 382:1564-1567.

22. Donders F, Lonnée-Homann R, Tsiakalos A, et al. Guidelines ISIDOG Recommendations Concerning COVID-19 and Pregnancy. Diagnostics (Basel) 2020; 10:243.

23. Poon LC, Yang $\mathrm{H}$, Kapur A, et al. Global interim guidance on coronavirus disease 2019 (COVID-19) during pregnancy and puerperium from FIGO and allied partners: Information for health care professionals. Int J Gynaecol Obstet 2020; 149:273-286.

24. Liang H, Acharya G. Novel coronavirus disease (COVID-19) in pregnancy: What clinical recommendations to follow? Acta Obstet Gynecol Scand 2020; 99:439-442.

25. Di Mascio D, Khalil A, Saccone G, et al. Outcome of coronavirus spectrum infections (SARS, MERS, COVID-19) during pregnancy: a systematic review and meta-analysis. Am J Obstet Gynecol MFM 2020; 2:100107.

26. The Australian and New Zealand Intensive Care Society (ANZICS): COVID-19 Guidlines Version 1. 2020. Available from: https:// www.anzics.com.au/wp-content/uploads/2020/03/ANZICSCOVID-19-Guidelines-Version-1.pdf. (Erişim tarihi: 22 Mayıs 2020)

27. Brigham and Women's Hospital. Brigham and Women's Hospital Covid-19 Critical Care Clinical Guidelines. Available from: https:// www.covidprotocols.org/. (Erişim tarihi: 24 Mayıs 2020)

28. Morau E, Bouvet L, Keita $\mathrm{H}$, et al. Anaesthesia and intensive care in obstetrics during the COVID-19 pandemic. Anaesth Crit Care Pain Med 2020; 39:345-349.

29. Isobe K, Iwata M, Ishida F, et al. A case of pulmonary alveolar hemorrhage caused by methylergometrine. Nihon Kokyuki Gakkai Zasshi 2008; 46:1007-1012.

30. Stephens AJ, Barton JR, Bentum NA, Blackwell SC, Sibai BM. General Guidelines in the Management of an Obstetrical Patient on the Labor and Delivery Unit during the COVID-19 Pandemic. Am J Perinatol 2020; 37:829-836.

31. Chen R, Zhang Y, Huang L, Cheng B-H, Xia Z-Y, Meng Q-T. Safety and efficacy of different anesthetic regimens for parturients with COVID-19 undergoing Cesarean delivery: a case series of 17 patients. Can J Anaest 2020; 67:655-663.

32. Little P. Non-steroidal anti-inflammatory drugs and covid-19. BMJ 2020; 368:m1185.

33. Thachil J, Tang N, Gando S, et al. ISTH interim guidance on recognition and management of coagulopathy in COVID-19. J Thromb Haemost 2020; 18:1023-1026. 
Volume 2 Number 3 p: 96-104

34. Dotters-Katz S, Hughes BL. Coronavirus (COVID-19) and Pregnancy: What Maternal-Fetal Medicine Subspecialists Need to Know. Society for Maternal-Fetal Medicine. Available from: https:// s3.amazonaws.com/cdn.smfm.org/media/2262/COVID19_PDF. pdf. (Erişim tarihi: 28 Mayıs 2020)

35. Zhang L, Jiang $\mathrm{Y}$, Wei M, et al. Analysis of the pregnancy outcomes in pregnant women with COVID-19 in Hubei Province. Zhonghua Fu Chan Ke Za Zhi 2020; 55:166-171.

36. Zeng H, Xu C, Fan J, et al. Antibodies in Infants Born to Mothers with COVID-19 Pneumonia. JAMA 2020; 323:1848-1849.

37. Chawla D, Chirla D, Dalwai S, et al. Perinatal-Neonatal Management of COVID-19 Infection - Guidelines of the Federation of Obstetric and Gynecological Societies of India (FOGSI), National Neonatology Forum of India (NNF), and Indian Academy of Pediatrics (IAP). Indian Pediatr 2020; 57:536-548.
38. Aslan MM, Yuvacı HU, Köse O, Cevrioğlu AS, Özden S. COVID-19 ve Gebelik. J Biotechnol and Strategic Health Res 2020;1:10-13.

39. UNMC Nebraska Medicine, Maternal Child Health Guidelines May 4, 2020. Available from: https://www.nebraskamed.com/sites/ default/files/documents/covid-19/maternal-child-health-guidelinescovid-19.pdf?date=05042020 . (Erişim tarihi: 2 Haziran 2020)

40. Davanzo R, Moro G, Sandri F, Agosti M, Moretti C, Mosca F. Breastfeeding and coronavirus disease-2019: Ad interim indications of the Italian Society of Neonatology endorsed by the Union of European Neonatal \& Perinatal Societies. Matern Child Nutr 2020; 16:e13010. 